УДК 612.015.1-02: 616.137.8/9-005.4-007.271] - 092.9

DOI 10.11603/2414-4533.2019.2.10418

(ОН. В. ВОЛОТОВСЬКА, О. Й. ЗАРІЧНА, І. П. КУЗЬМАК

ДВНЗ “Тернопільський державний медичний університет імені І. Я. Горбачевського МОЗ України”

\title{
Активність каталази та супероксиддисмутази на тлі експериментальної ішемії-реперфузії кінцівки
}

\begin{abstract}
Мета роботи: встановити динаміку активності супероксиддисмутази та каталази нирок на тлі модифікацій ішемічнореперфузійного синдрому (IPC).

Матеріали і методи. У експерименті використовували 210 нелінійних білих щурів-самців віком 5-5,5 місяця. Досліджено динаміку активності антиоксидних ферментів (каталаза (Кат), супероксиддисмутаза (СОД)) у тканині нирки в умовах моделювання модифікацій ішемічно-реперфузійного синдрому (IPC). Забір зразків тканини здійснювали через 24 години, на 3, 7, 14 доби після травми. Щури виведені з експерименту методом тотального кровопускання з верхівки серця.

Результати досліджень та їх обговорення. У наших моделях IPC рівень Кат в основному зменшувався в кожному періоді експерименту. Пік активності СОД спостерігався на 1, 3 добу або пригнічення (здебільшого на 3 добу) після експериментального IPC - згідно з модифікаціями ступенів тяжкості травми. Таким чином, застосування кровоспинного джгута в поєднанні з втратою крові та механічною травмою спричиняли суттєві ураження антиоксидної системи нирок. При цьому навіть одноразове застосування джгута зумовлювало подібні хвилеподібні реакції. Загалом розвиток IPC супроводжується сильним пригніченням антиоксидної системи нирки.
\end{abstract}

Ключові слова: ішемічно-реперфузійний синдром; нирка; травма; крововтрата; гемостатичний джгут; каталаза; супероксиддисмутаза.

Постановка проблеми і аналіз останніх досліджень та публікацій. Ушкодження як скелетних м’язів, так і внутрішніх органів на тлі локальних процесів ішемії-реперфузії з метою зупинки кровотечі з ураженої кінцівки чи інтраопераційно вивчаються давно [1-10]. Механічний тиск від гемостатичного джгута створює первинне ушкодження м'яких тканин, судин та нервів. Що стосується вторинних механізмів - за це відповідальні вільні радикали кисню і перекисне окиснення ліпідів [11]. Крововтрата при цивільній та бойовій травмі кінцівок є найпоширенішою причиною превентивної смерті, особливо якщо брати до уваги ускладнення внаслідок використання гемостатичного джгута. Останні можуть бути набагато серйознішими, ніж це вважалося раніше.

Окисний стрес відіграє провідну роль у розвитку сприятливих умов для місцевого й системного ураження, а в подальшому прогресу реперфузійних ускладнень в умовах кисневої недостатності тканин [12]. Надпродукція активних форм кисню поєднується з порушенням активності окисновідновних систем, ДНК, мембранних рецепторів, функції іонних каналів, складу мембранних фосфоліпідів, а також активацією каспазного механізму апоптозу $[13,14,15]$, що, зрештою, призводить до активації ендогенного антиоксидантного захисту [13, 16-22].

Клітинні системи антиоксидного захисту класифікуються як ферментативні і неферментативні. Перший включає супероксиддисмутазу (СОД), глу- татіонпероксидазу (ГП) і каталазу (Кат), які забезпечують першу лінію захисту від дії активних форм кисню у спосіб, коли продукт першої реакції стає субстратом для наступної [23, 24]. Нині встановлено, що механічна травма, ішемія суттєво пригнічують активність ферментної ланки антиоксидного захисту [25, 26 ]. Однак при збереженні балансу між компенсаторними та патогенними механізмами безперечну роль досліджуваних ферментів складно переоцінити. Так, гіперекспресія СОД запобігає загибелі нейронів гіпокампу [27]. У деяких дослідженнях ГП забезпечує ще більший захист від окисного стресу, ніж СОД - ії активність, як і СОД, має цитопротекторну дію $[16,18]$. Кат - важливий елемент підтримки внутрішньоклітинної концентрації відновленого глутатіону, відіграє вирішальну роль у нейтралізації вільних радикалів [27, 28].

Різні методи використовуються в даний час із терапевтичною метою - від зниження температури кінцівки до застосування різних препаратів. Таким чином, захисний ефект куркуміну на міокард, нирки, нервову тканину і легені доведено на тлі згаданої вище патології [29-32]. Монтелукаст знижує рівень локальних і системних проявів [32], легалон, тіотриазолін, емоксипін, силімарин мають антиоксидну дію [3-9, 28-33]. Вивчення змін їхньої активності необхідне для прогнозування застосування специфічного лікування антиоксидними коректорами. Це буде важливим кроком для уникнення виснаження васних захисних систем ушкодженого організму [34-39]. 
Мета роботи: вивчити особливості реакції ферментної ланки антиоксидної системи нирок на тлі модифікацій IPC.

Матеріали і методи. Експерименти проводили на 210 нелінійних білих щурах-самцях масою 250-270 г 5-5,5 місячного віку. Їх розділили на 5 груп по 10 тварин в кожній: контрольна, де щурів вводили тільки в анестезію тіопентал-натрієм (40 мг/кг маси тіла інтраперитонеально), 1 дослідна група (джгут накладено на верхню $1 / 3$ стегна протягом 2 годин; 2 дослідна група (моделювання крововтрати в обсязі 40 \% від об'єму циркулюючої крові зі стегнової вени; 3 дослідна група (джгут на стегна був поєднаний з крововтратою 40 \% на іншій нижній кінцівці); 4 дослідна група (джгут на стегно поєднувався з переломом стегнової кістки іншої нижньої кінцівки); 5 дослідна група (джгут на стегно поєднаний з 40 \% крововтратою і переломом стегнової кістки іншої нижньої кінцівки).

Досліди проводили вранці у спеціальних приміщеннях віварію ТДМУ імені І. Я. Горбачевського зі стабільною температурою $\left(18-22{ }^{\circ} \mathrm{C}\right)$, відносною вологість (40-60 \%) і освітленням 250 лк. Тварин виводили з експерименту на 1, 3, 7 і 14 доби після травми з допомогою тіопентал-натрієвої анестезії (40 мг / кг маси тіла інтраперитонеально) шляхом тотальної кровотечі з серця. Про стан системи антиоксидного захисту дізнавалися за рівнями активності СОД (метод, описаний Чеварі С.) та каталазної активності (за Королюк М. А.) нирок.

Всі експериментальні етапи роботи виконано відповідно до Європейської конвенції про захист хребетних тварин, що використовуються 3 метою експериментальних та інших наукових цілей (Страсбург, 1986 р.), Резолюції Першого національного конгресу з біоетики (Київ, 2001 р.) та наказу Міністерство охорони здоров'я України № 690 від 23 вересня 2009 року.

Статистичний аналіз отриманих даних проводили Excel (Microsoft, США). Статистичну значущість відмінностей між незалежними індексами оцінювали за допомогою коефіцієнта Стьюдента при нормальному розподілі та непараметричними методами в інших випадках. Результати представлені у вигляді $(\mathrm{M} \pm \mathrm{m})$, де М означає значення, $\mathrm{m}$ - стандартна похибка. Проведено кореляційний аналіз отриманих даних.

Результати досліджень та їх обговорення. Особливості активності досліджуваних ферментів нирки представлено в таблиці.

На першу добу, порівняно з контролем, спостерігалося збільшення СОД на 41,2 \% $\left(\mathrm{p}_{1}<0,008\right)$, на

Таблиця. Зміни активності супероксиддисмутази (spec.un / мг) і каталази (мккат / кг) у гомогенатах печінки 10 \% щурів на основі модифікації ішемічної реперфузійної травми та ізольованої крововтрати (М \pm m)

\begin{tabular}{|c|c|c|c|c|c|c|c|}
\hline \multicolumn{2}{|c|}{ Група } & & 1 & 2 & 3 & 4 & 5 \\
\hline $\begin{array}{l}\text { Період після } \\
\text { травми }\end{array}$ & Контроль & & $\begin{array}{c}\text { Джгут } \\
\text { (Д) }\end{array}$ & $\begin{array}{c}\text { Крововтрата } \\
\text { (К) }\end{array}$ & Д+K & $\begin{array}{c}\text { Д+МТ (механічна } \\
\text { травма) }\end{array}$ & Д+K+MT \\
\hline \multirow[t]{2}{*}{$\begin{array}{l}\text { Через } 24 \text { год } \\
\text { після травми }\end{array}$} & \multirow[t]{2}{*}{$\begin{array}{l}\text { СОД } \\
0,464 \pm 0,05\end{array}$} & СОД & $\begin{array}{c}0,655 \pm \\
0,04 *\end{array}$ & $\begin{array}{c}0,546 \pm \\
0,04\end{array}$ & $\begin{array}{c}0,184 \pm \\
0,03 *\end{array}$ & $\begin{array}{c}0,278 \pm \\
0,02 *\end{array}$ & $\begin{array}{c}0,771 \pm \\
0,02 *\end{array}$ \\
\hline & & Кат & $\begin{array}{c}0,399 \pm \\
0,03^{*}\end{array}$ & $\begin{array}{c}0,558 \pm \\
0,03^{*}\end{array}$ & $\begin{array}{c}5,187 \pm \\
0,04 *\end{array}$ & $\begin{array}{l}6,162 \pm \\
0,014^{*}\end{array}$ & $\begin{array}{c}0,483 \pm \\
0,03 *\end{array}$ \\
\hline \multirow[t]{2}{*}{$\begin{array}{l}3 \text { доба після } \\
\text { трамви }\end{array}$} & \multirow{6}{*}{$\begin{array}{l}\text { Кат } \\
3,103 \pm 0,33\end{array}$} & СОД & $\begin{array}{c}0,534 \pm \\
0,03\end{array}$ & $\begin{array}{c}0,763 \pm \\
0,03^{*} * *\end{array}$ & $\begin{array}{c}0,149 \pm \\
0,16^{*}{ }^{* * *}\end{array}$ & $\begin{array}{c}0,155 \pm \\
0,06^{*} * *\end{array}$ & $\begin{array}{c}0,134 \pm \\
0,05^{*} * *\end{array}$ \\
\hline & & Кат & $\begin{array}{c}0,371 \pm \\
0,03^{*}\end{array}$ & $\begin{array}{c}0,383 \pm \\
0,02 * * *\end{array}$ & $\begin{array}{l}4,141 \pm \\
0,6^{*} * *\end{array}$ & $\begin{array}{l}4,827 \pm \\
0,2^{*} * *\end{array}$ & $\begin{array}{l}3,392 \pm \\
0,4^{*} * *\end{array}$ \\
\hline \multirow[t]{2}{*}{$\begin{array}{l}7 \text { доба після } \\
\text { трамви }\end{array}$} & & СОД & $\begin{array}{c}0,587 \pm \\
0,03\end{array}$ & $\begin{array}{c}0,535 \pm \\
0,03^{*} * *\end{array}$ & $\begin{array}{c}0,582 \pm \\
0,06^{*}{ }^{\prime} * * * * *\end{array}$ & $\begin{array}{c}0,657 \pm \\
0,03^{*}{ }^{*} * * * * *\end{array}$ & $\begin{array}{c}0,544 \pm \\
0,04{ }^{*}{ }_{* *}{ }_{* * *}\end{array}$ \\
\hline & & Кат & $\begin{array}{l}0,968 \pm \\
0,2^{*}, * *\end{array}$ & $\begin{array}{c}0,433 \pm \\
0,06 * 6^{* * *}\end{array}$ & $\begin{array}{c}2,933 \pm \\
0,4^{* *}{ }^{*} * *\end{array}$ & $\begin{array}{c}0,264 \pm \\
0,03^{*}{ }^{*} * * * * *\end{array}$ & $\begin{array}{c}2,480 \pm \\
0,1^{*}{ }^{*} * * * *\end{array}$ \\
\hline \multirow[t]{2}{*}{$\begin{array}{l}14 \text { доба після } \\
\text { трамви }\end{array}$} & & СОД & $\begin{array}{l}0,459 \pm \\
0,03 * *\end{array}$ & $\begin{array}{l}0,461 \pm \\
0,04 * *\end{array}$ & $\begin{array}{c}0,756 \pm \\
0,03^{*}{ }^{\prime} * * *^{*} * *\end{array}$ & $\begin{array}{c}0,314 \pm \\
0,05^{*}{ }^{*}{ }^{\prime}, * * *\end{array}$ & $\begin{array}{c}0,625 \pm \\
0,06^{*}{ }^{\prime} * * * * * *\end{array}$ \\
\hline & & Кат & $\begin{array}{c}3,440 \pm \\
0,06^{* *} \#\end{array}$ & $\begin{array}{c}0,390 \pm \\
0,05^{*} * *\end{array}$ & $\begin{array}{c}0,352 \pm \\
0,03^{*}{ }^{*} * *^{\prime} * * * ;\end{array}$ & $\begin{array}{c}2,017 \pm \\
0,3^{*}{ }^{*} * * * * *\end{array}$ & $\begin{array}{c}3,417 \pm \\
0,03^{*}{ }^{* * *} \#\end{array}$ \\
\hline
\end{tabular}

Примітки: * - статистично значущі показники порівняно з контролем;

** - статистично значущі показники порівняно 31 добою;

*** - статистично значущі показники порівняно з 3 добою;

\# - статистично значущі показники порівняно $з 7$ добою. 
$11,2 \%\left(\mathrm{p}_{2}<0,008\right)$, на $66,2 \%\left(\mathrm{p}_{5}<0,002\right)$, тоді як на тлі застосування турнікету з крововтратою чи поєднаного з механічною травмою - зафіксовано зниження активності - в 2,5 раза $\left(\mathrm{p}_{3}<0,005\right)$ та на $60 \%$ $\left(\mathrm{p}_{4}<0,03\right)$. Що стосується Кат, то ії рівень на першу добу був прямо протилежний до активності СОД: спостерігалося зниження в 7,78 раза $\left(\mathrm{p}_{1}<0,005\right)$, в 5,6 раза $\left(\mathrm{p}_{2}<0,005\right)$, в 6,4 раза $\left({ }_{\mathrm{p} 5}<0,007\right)$, але збільшилася на $67,2 \%\left(\mathrm{p}_{3}<0,005\right)$ і в 2 рази $\left(\mathrm{p}_{4}<0,007\right)$.

На 3 добу після травми, порівняно з контролем, у дослідних групах , де було ізольоване застосування травмуючого чинника, зафіксовано підвищення активності СОД: на 15,1 \% ( $\left.\mathrm{p}_{1}<0,006\right)$, на $64,4 \%$ $\left(\mathrm{p}_{2}<0,008\right)$; тоді як при поєднанні ішемії-реперфузії 3 крововтратою чи механічною травмою динаміка була депресивною: в 3,1 раза (р3 $<0,007)$, у 3 рази $\left(\mathrm{p}_{4}<0,009\right)$, та у 3,5 раза $\left(\mathrm{p}_{5}<0,01\right)$. Що стосується Кат, то динаміка, як і в попередньому дослідному періоді, виявилася протилежною - на тлі зниження активності СОД зафіксовано збільшення активності Кат. Так, зниження рівня в 8,4 раза (p1<0,007), у 8,1 раза (р2 <0,006), тоді як у решті випадків зростання активності на 33,5 \% ( $\left.\mathrm{p}_{3}<0,07\right)$, у 55,6\% $\left(\mathrm{p}_{4}<0,04\right)$, на $9,1 \%\left(\mathrm{p}_{5}<0,08\right)$.

На 7 добу, порівняно з контролем, спостерігалося хоч і незначне, але стабільне збільшення активності СОД у всіх дослідних групах: на $26,5 \%\left(\mathrm{p}_{1}<0,006\right)$, на $15,3 \%\left(\mathrm{p}_{2}<0,008\right)$, на $25,4 \%$ $\left(\mathrm{p}_{3}<0,006\right)$, на $17,2 \%\left(\mathrm{p}_{5}<0,007\right)$ і тільки на тлі механічної травми, поєднаної з IP, зафіксовано зростання активності СОД на 41,6 \% ( $\left.\mathrm{p}_{4}<0,007\right)$. У всіх групах також встановлено зниження рівня активності каталази - у 3,2 раза $\left(\mathrm{p}_{1}<0,1\right)$, у 7,2 раза $\left(\mathrm{p}_{2}<0,01\right)$, на $5,5 \%\left(\mathrm{p}_{3}<0,05\right)$, у 11,8 раза $\left(\mathrm{p}_{4}<0,006\right)$, та на 20,1\% ( $\left.\mathrm{p}_{5}<0,04\right)$.

Динаміка СОД на 14 добу була мінливою, але вказувала на відновлення компенсаторних мож-

\section{СПИСОК ЛІТЕРАТУРИ}

1. Khanna A. Nitric oxide and skeletal muscle reperfusion injury: current controversies (research review) / A. Khanna, P. A. Cowled, R. A. Fitridge // Journal of Surgical Research. 2005. - Vol. 128(1). - P. 98-107.

2. Wang W. Z. Update on ischemia-reperfusion injury for the plastic surgeon // W. Z. Wang, R. S. Baynosa, W. A. Zamboni // Plastic and Reconstructive Surgery. - 2011. - Vol. 128 (6). P. 685-692.

3. Van der Spuy L. Complications of the arterial tourniquet / L. Van der Spuy // Journal Southern African Journal of Anaesthesia and Analgesia - 2012. - Vol. 18 (1). - P. 14-18

4. Does tourniquet use in TKA affect recovery of lower extremity strength and function? A randomized trial / D. A. Dennis, A. Kittelson, C. C. Yang [et al.] // Clinical Orthopaedics and Related Research. - 2016. - Vol. 474 (1). - P. 69-77.

5. Influence of tourniquet application on venous blood sampling for serum chemistry, hematological parameters, leukocyte ливостей антиоксидної системи досліджуваного органа. На тлі ізольованого джгута та крововтрати показники відповідали вихідному рівню, тоді як на тлі модифікацій IPC зафіксовано зростання активності СОД, порівняно з вихідним рівнем. Відбулось підвищення ії рівня на $63 \%\left(\mathrm{p}_{3}<0,007\right)$, на $34,7 \%\left(\mathrm{p}_{5}<0,008\right)$. I тільки на тлі механічної травми, поєднаної з джгутом, виявлено незначне зниження активності СОД - як відносно вихідного рівня, так і відносно попереднього досліджуваного періоду (на 7добу) $\left(\mathrm{p}_{4}<0,05\right)$.

Що стосується Кат, то це була в основному динаміка депресії: зниження рівня активності, порівняно з контролем, в 7,95 раза $\left(\mathrm{p}_{2}<0,007\right)$, у 8,8 раза ( $\mathrm{p}_{3}<0,0048$, на $35 \%\left(\mathrm{p}_{4}<0,05\right)$, на $22,1 \%$ $\left(\mathrm{p}_{5}<0,007\right)$. I тільки на тлі ізольованого застосування джгута зафіксовано зростання, порівняно 3 вихідним рівнем, на $10 \%\left(\mathrm{p}_{1}<0,01\right)$.

Висновки. На фоні активації перекисного окиснення ліпідів і окисного стресу, за даними літератури, спостерігається різний рівень активності ферментів системи антиоксидного захисту в усіх органах ураженого організму. Порівняння отриманих нами попередньо результатів антиоксидної активності печінки з активністю СОД та Кат в нирках показало дещо нижчий рівень відповіді в останній, хоча картина динаміки збереглася.

Навіть одноразове використання гемостатичного джгута сприяло значним змінам активності ферментативного рівня антиоксидного захисту. Як і в реальних військових умовах, крововтрата часто поєднується з травмами скелета, доцільно вчасно обмежити використання гемостатичного джгута або вжити заходів, які протидіють зростанню перекисного окиснення ліпідів в результаті травм.

activation and erythrocyte mechanical properties / M. Cengiz, P. Ulker, O. K. Bashkurt // Clinical Chemistry and Laboratory Medicine. - 2009. - Vol. 47 (6). - P. 769-776.

6 . Tuncali B. Tourniquet pressure settings based on limb occlusion pressure determination or arterial occlusion pressure estimation in total knee arthroplasty? A prospective, randomized, double blind trial / B. Tuncali, H. Boya, Z. Kayhan, S. Arac // Acta Orthopaedica et Traumatologica Turcica. - 2018. - Vol. 52 (4). - P. 256-260.

7. Rao P. R. Cardioprotective activity of silymarin in ischemiareperfusion-induced myocardial infarction in albino rats / P. R. Rao, R. K. Viswanath // Experimental and Clinical Cardiology. - 2007. - Vol. 12 (4). - P. 179-187.

8. Antioxidant and mitochondrial protective effects of silibinin in cold preservation-warm reperfusion liver injury / H. Ligeret, A. Brault, D. Vallerand, Y. Haddad, P. S. Haddad // Journal of Ethnopharmacology. - 2008. - Vol. 115 (3). - P. 507-514. 
9. Silymarin attenuates the renal ischemia/reperfusion injuryinduced morphological changes in the rat kidney / H. Senturk, S. Kabay, G. Bayramoglu [et al.] // World Journal of Urology. 2008. - Vol. 26 (4). - P. 401-407.

10. Preventive effect of silymarin in cerebral ischemia-reperfusioninduced brain injury in rats possibly through impairing NF-B and STAT-1 activation / Y. C. Hou, K. T. Liou, C. M. Chern [et al.] // Phytomedicine. - 2010. - Vol. 17 (12). - P. 963-973.

11. Superoxide dismutase activity and the effects of NBQX and CPP on lipid peroxidation in experimental spinal cord injury / A. Görgülü, T. Kırış, F. Ünal [et al.] // Research in Experimental Medicine. - 1999. - Vol. 199 (5). - P. 285-293.

12. Ergün Yu. Antioxidant effect of Legalon(r) SIL in ischemiareperfusion injury of rat skeletal muscle / Yu. Ergün, M. Üremis, M. Kılınç, T. Alıcı // Acta Cirurgica Brasiliera. - 2016. - Vol. 31 (4). - P. 264-270.

13. Alterations in superoxide dismutase, glutathione peroxidase and catalase activities in experimental cerebral ischemia-reperfusion / S. Işlekel, H. Işlekel, G. Güner [et al.] // Journal of Clinical and Experimental Research. - 1999. - Vol. 199. - P. 67-76.

14. Role of oxygen radicals in DNA damage and cancer incidence / M. Valko, M. Izakovic, M. Mazur [et al.] // Molecular and Cellular Biochemistry. - 2004. - Vol. 266. - P. 37-56.

15. Yukio I. Superoxide dismutase activity in experimental brain tumors - determination by electron spin resonance spectrometry using the spin trap method / I. Yukio, N. Shozo, Y. Masako // Biological Aspects of Brain Tumors. - 1991. - Springer, Tokyo. - P. 184-185.

16. The cytosolic antioxidant, copper/zinc superoxide dismutase, attenuates blood-brain barrier disruption and oxidative cellular injury after photothrombotic cortical ischemia in mice / G. W. Kim, A. Lewen, J. Copin [et al.] // Neuroscience. - 2001. - No. 105. - P. 7-18.

17. Post-stroke inhibition of induced NADPH oxidase type 4 prevents oxidative stress and neurodegeneration / C. Kleinschnitz, H. Grund, K. Wingler [et al.] // PLoS Biology. - 2010. - Vol. 8. - P. 1-13.

18. Kofler J. SOD1 overexpression and female sex exhibit regionspecific neuroprotection after global cerebral ischemia due to cardiac arrest / J. Kofler, P. D. Hurn, R. J. Traystman // Journal of Cerebral Blood. Flow and Metabolism. - 2005. - Vol. 25. P. 11-30.

19. Oxidative stress and pathophysiology of ischemic stroke: novel therapeutic opportunities / R. Rodrigo, R. FernandezGajardo, R. Gutierrez [et al.] // CNS \& Neurological Disorders Drug Targets. - 2013. - Vol. 12. - P. 698-714.

20. Free radicals and antioxidants in normal physiological functions and human disease / M. Valko, D. Leibfritz, J. Moncol [et al.] // The International Journal of Biochemistry \& Cell Biology. - 2007. - Vol. 39. - P. 44-84.

21. Neuroprotection of posttreatment with risperidone, an atypical antipsychotic drug, in rat and gerbil models of ischemic stroke and the maintenance of antioxidants in a gerbil model of ischemic stroke / B. C. Yan, J. H. Park, J. H. Ahn [et al.] // Journal of Neuroscience Research. - 2014. - Vol. 92. - P. 795-807.

22. Neuroprotective effects of N-stearoyltyrosine on transient global cerebral ischemia in gerbils / Y. B. Zhang, M. Y. Kan, Z. H. Yang [et al.] // Brain Research. - 2009. - Vol. 1287. P. 146-156.

23. Орлова Е. А. Активность цитозольной супероксиддисмутазы в тканях крыс разного возраста на фоне применения парафармацевтика «Вин-Вита» / Е. А. Орлова, О. А. Лазарчук // Український журнал клінічної та лабораторної медицини. 2010. - T. 5(3). - C. 87-90.

24. Steare S. E. The protective effect of heat stress against reperfusion arrhythmias in the rat / S. E. Steare, D. M. Yellon //
Journal of Molecular and Cellular Cardiology. - 1993. - Vol 25. - P. 71-81.

25. Цимбалюк Г. Ю. Динаміка змін в антиоксидантно-прооксидантній системі в тканинах нирок при травмі органів черевної порожнини на фоні гіповолемічного шоку та синдрому ішемії-реперфузії / Г. Ю. Цимбалюк // Шпитальна хірургія. Журнал імені Л. Я. Ковльчука . - 2018. - № 3. - С. 63-69. 26. Кащак Т. В. Інтенсивність процесів ліпідної пероксидації та рівень маркерів запалення в пізній період комбінованої травми в експерименті / Т. В. Кащак, А. А. Гудима // Шпитальна хірургія. Журнал імені Л. Я. Ковальчука. - 2018. № 4. - С. 62-78.

27. Сравнение антиоксидантной активности мексидола при повреждениях головного мозга различного генеза в эксперименте / А. В. Воронков, Д. И. Поздняков, Е. И. Рури, А. Е. Рыбалко // Современные проблемы науки и образования. - 2016. - № 6. URL: http://www.science-education.ru/ru/ article/view?id=25392.

28. Takhtfooladi H. A. Effect of curcumine on lung injury induced by skeletal muscle ischemia / reperfusion in rats / H. A. Takhtfooladi, M. A. Takhtfooladi // Turkish Journal of Trauma and Emergency Surgery. - 2019. - Vol. 25 (1). - P. 7-11.

29. Effect of low-level laser therapy on lung injury induced by hindlimb ischemia / reperfusion in rats / M. A. Takhtfooladi, H. A. Takhtfooladi, H. Sedaghatfar, S. Shabani // Lasers in Medical Science. - 2015. - Vol. 30. - P. 1757-1762.

30. Multiple actions of the coumarine derivative cloricromene and its protective effects on ischemic brain injury / G. Calapai, F. Squadrito, A. Rizzo [et al.] // Naunyn-Schmiedeberg's Archives of Pharmacology. - 1995. - Vol. 351 (2). - P. 209-215.

31. Erythropoietin protects against brain ischemic injury by inhibition of nitric oxide formation / G. Calapai, M. C. Marciano, F. Corica [et al.] // European Journal of Pharmacology. - 2000. Vol. 401(3). - P. 349-356.

32. The protective effect of Montelukast against skeletal muscle ischemia / reperfusion injury: An experimental rat model / M. İ. Bilgiç, G. Altun, H. Cakici [et al.] // Turkish Journal of Trauma and Emergency Surgery. - 2018. - Vol. 24 (3). - P. 185-190.

33. The effect of silymarin on mesenteric ischemia-reperfusion injury / M. Demir, R. Amanvermez, A. P. Kamali [et al.] // Medical Principles and Practice. - 2014. - Vol. 23 (2). - P. 140-144.

34. Pathogenesis of myocardial ischemia-reperfusion injury and rationale for therapy / T. Aslan, M. D. Turer, A. Joseph, M. D. Hill // The American Journal of Cardiology. - 2010. Vol. 106 (3). - P. 360-368.

35. Погляди на тимчасові методи зупинки кровотечі в умовах бойовиїх дій / В. С. Тарасюк, М. В. Матвійчук, І. В. Паламар [та ін.] / Вісник Вінницького Нац. Ун-ту. - 2017. - Вип. 1 (2, 21). - C. 220-227.

36. Contemporary outcomes of endovascular interventions for acute limb ischemia / R. M. Byrne, A. G. Taha, E. Avgerinos [et al.] // Journal of Vascular Surgery. - 2014. - Vol. 59 (4). P. 988-995.

37. Acute limb ischemia: contemporary approach / I. Fukuda, M. Chiyoya, S. Taniguchi, W. Fukuda // The Journal of Thoracic and Cardiovascular Surgery. - Vol. 63 (10). - P. 540-548.

38. Цимбалюк Г. Ю. Стан добового діурезу нирок в умовах ішемічно-реперфузійного синдрому кінцівок, травми органів черевної порожнини, ускладненої гіповолемічним шоком, та їх поєднання у ранньому періоді травматичної хвороби / Г. Ю. Цимбалюк // Здобутки клінічної і експериментальної медицини. - 2018. - № 3. - С. 163-169.

39. Salvadori M. Update on ischemia-reperfusion injury in kidney transplantation: Pathogenesis and treatment / M. Salvadori, G. Rosso E. Bertoni // World J. Transplant. - 2015. - Vol. 5. P. 52-67. PubMed/NCBI 


\section{REFERENCES}

1. Khanna, A., Cowled, P.A., \& Fitridge, R.A. (2005). Nitric oxide and skeletal muscle reperfusion injury: current controversies (research review). Journal of Surgical Research, 1, 128 (1), 98107. https://doi.org/10.1016/j.jss.2005.04.020 PMid:15961106

2. Wang, W.Z., Baynosa, R.C., \& Zamboni, W.A. (2011). Update on ischemia-reperfusion injury for the plastic surgeon: 2011. Plastic and Reconstructive Surgery, 128 (6), 685e-92e. Retrieved from: https://doi.org/10.1097/PRS.0b013e318230c57b PMid:22094770

3. Van der Spuy L. (2012). Complications of the arterial tourniquet. South Afr. J. Anaesth. Analg., 18 (1), 14-18. Retrieved from: https://doi.org/10.1080/22201173.2012.10872818

4. Dennis, D.A., Kittelson, A.J., Yang, C.C., Miner, T.M., Kim, R.H., \& Stevens-Lapsley J.E. (2016). Does tourniquet use in TKA affect recovery of lower extremity strength and function? A randomized trial. Clin. Orthop. Relat. Res., 474 (1), 69-77. Retrieved from: https://doi: 10.1007/s11999-015-4393-8. https:// www.ncbi.nlm.nih.gov/pubmed/26100254

5. Cengiz, M., Ulker, P., Bashkurt, O.K., \& Cengiz, M. (2009). Influence of tourniquet application on venous blood sampling for serum chemistry, hematological parameters, leukocyte activation and erythrocyte mechanical properties. Clin. Chem. Lab Med., 47 (6), 769-776. Retrieved from: https://doi: 10.1515/ CCLM.2009.157.

6. Tuncali, B., Boya, H., Kayhan, Z., \& Arac, S. (2018). Tourniquet pressure settings based on limb occlusion pressure determination or arterial occlusion pressure estimation in total knee arthroplasty? A prospective, randomized, double blind trial. Acta Orthop. Traumatol. Turc., 52 (4), 256-260. https://doi. org/10.1016/j.aott.2018.04.001

7. Rao, P.R., \& Viswanath, R.K. Cardioprotective activity of silymarin in ischemia-reperfusion-induced myocardial infarction in albino rats. Exp. Clin. Cardiol., 12 (4), 179-87.

8. Ligeret, H., Brault, A., Vallerand, D., Haddad, Y., \& Haddad, P.S. (2008). Antioxidant and mitochondrial protective effects of silibinin in cold preservation-warm reperfusion liver injury. J. Ethnopharmacol., 115 (3), 507-514. Retrieved from: https://doi.org/10.1016/j.jep.2007.10.024 PMid:18061382

9. Senturk, H., Kabay, S., Bayramoglu, G., Ozden, H., Yaylak, F., Yucel, M., Olgun, E.G., \& Kutlu, A. (2008). Silymarin attenuates the renal ischemia/reperfusion injury-induced morphological changes in the rat kidney. World J. Urol., 26 (4), 401-407. Retrieved from: https://doi.org/10.1007/s00345-008-0256-1 PMid:18408933 10. Hou, Y.C., Liou, K.T., Chern, C.M., Wang, Y.H., Liao, J.F., Chang, S., Chou, Y.H., \& Shen, Y.C. (2010). Preventive effect of silymarin in cerebral ischemia-reperfusion-induced brain injury in rats possibly through impairing NF-?B and STAT-1 activation. Phytomedicine, 17 (12), 963-973. Retrieved from: https://doi. org/10.1016/j.phymed.2010.03.012 PMid:20833521

11. Görgülü, A., Kiriş, T., Unal, F., Turkoğlu, U., Küçük, M., Cobanoğlu, S. (2000). Superoxide dismutase activity and the effects of NBQX and CPP on lipid peroxidation in experimental spinal cord injury. Res. Exp. Med. (Berl)., 199 (5), 285-293. Retrieved from: https://doi.org/10.1007/s004330050126

12. Ergün, Yu., Üremis, M., Kılınç, M., \& Alıcı, T. (2016). Antioxidant effect of Legalon(r) SIL in ischemia-reperfusion injury of rat skeletal muscle. Acta Cir. Bras., 31 (4), 264-270. Retrieved from: https://doi. org/10.1590/S0102-865020160040000007 PMid:27168539

13. Işlekel, S., Işlekel, H., \& Güner, G. (1999). Alterations in superoxide dismutase, glutathione peroxidase and catalase activities in experimental cerebral ischemia-reperfusion. Res. Exp. Med., 199, 67-76. Retrieved from: https://doi.org/10.1007/ s004330050121 PMid:10639700
14. Valko, M., Izakovic, M., Mazur, M., Rhodes, C.J., \& Telser, J. (2004). Role of oxygen radicals in DNA damage and cancer incidence. Mol. Cell Biochem., 266 (1-2), 37-56. Retrieved from: https://doi. org/10.1023/B:MCBI.0000049134.69131.89 PMid:15646026

15. Yukio, I., Shozo, N., \& Masako, Y. (1991). Superoxide dismutase activity in experimental brain tumors - determination by electron spin resonance spectrometry using the spin trap method. Biological Aspects of Brain Tumors. Springer, Tokyo. 16. Kim, G.W., Lewen, A., \& Copin, J. (2001). The cytosolic antioxidant, copper/zinc superoxide dismutase, attenuates blood-brain barrier disruption and oxidative cellular injury after photothrombotic cortical ischemia in mice. Neuroscience, 105 (4), 1007-1018. Retrieved from: https://doi.org/10.1016/S0306-4522(01)00237-8

17. Kleinschnitz, C., Grund, H., \& Wingler, K. (2010). Poststroke inhibition of induced NADPH oxidase type 4 prevents oxidative stress and neurodegeneration. PLoS Biology, 8, 1-13. Retrieved from: https://doi.org/10.1371/journal.pbio.1000479 PMid:20877715 PMCid:PMC2943442

18. Kofler, J., Hurn, P.D., \& Traystman, R.J. (2005). SOD1 overexpression and female sex exhibit region-specific neuroprotection after global cerebral ischemia due to cardiac arrest. J. Cereb Blood. Flow. Metab., 25, 11-30. Retrieved from: https://doi.org/10.1038/sj.jcbfm.9600119 PMid:15843790

19. Rodrigo, R., Fernandez-Gajardo, R., \& Gutierrez, R. (2013). Oxidative stress and pathophysiology of ischemic stroke: novel therapeutic opportunities. CNS Neurol. Disord. Drug Targets, 12, 698-714. Retrieved from: https://doi. org/10.2174/1871527311312050015 PMid:23469845

20. Valko, M., Leibfritz, D., \& Moncol, J. (2007). Free radicals and antioxidants in normal physiological functions and human disease. Int. J. Biochem. Cell. Biol., 39, 44-84. Retrieved from: https://doi.org/10.1016/j.biocel.2006.07.001 PMid:16978905 21. Yan, B.C., Park, J.H., \& Ahn, J.H. (2014). Neuroprotection of posttreatment with risperidone, an atypical antipsychotic drug, in rat and gerbil models of ischemic stroke and the maintenance of antioxidants in a gerbil model of ischemic stroke. J. Neurosci. Res., 92, 795-807. Retrieved from: https://doi.org/10.1002/ jnr.23360 PMid:24481585

22. Zhang, Y.B., Kan, M.Y., \& Yang, Z.H. (2009). Neuroprotective effects of N-stearoyltyrosine on transient global cerebral ischemia in gerbils. Brain Res., 1287, 146-156. Retrieved from: https://doi. org/10.1016/j.brainres.2009.06.070 PMid:19563790

23. Orlova, E.A., \& Lazarchuk, O.A. (2010). Aktivnost tsitozolnoy superoksiddismutazyi v tkanyah krys raznogo vozrasta na fone primeneniya parafarmatsevtika "Vin-Vita" [The activity of cytosolic superoxide dismutase in tissues of rats of different ages with the use of parapharmaceutical "Vin-Vita"]. Ukrainskyi zhurnal klinichnoi ta laboratornoi medytsyny - Ukrainian Journal of Clinical and Laboratory Medicine, 5 (3):, 87-90 [in Russian]. 24. Steare, S.E., \& Yellon, D.M. (1993). The protective effect of heat stress against reperfusion arrhythmias in the rat. J. Mol. Cell. Cardiol., 25, 71-81. Retrieved from: https://doi.org/10.1006/ jmcc.1993.1163 PMid:8158665

25. Tsymbaliuk, H.Yu. (2018). Dynamika zmin v antyoksydantnoprooksydantnii systemi $\mathrm{v}$ tkanynakh nyrok pry travmi orhaniv cherevnoi porozhnyny na foni hipovolemichnoho shoku ta syndromu ishemii-reperfuzii [Dynamics of changes in the antioxidant-prooxidant system in kidney tissues during abdominal trauma on the background of hypovolemic shock and ischemiareperfusion syndrome]. Shpytalna khirurhiia. Zhurnal imeni L.Ya. Kovalchuka - Hospital Surgery. Journal named after L.Ya. Kovalchuk, 3, 63-69. Retrieved from: http://nbuv.gov.ua/ UJRN/shpkhir_2018_3_10 
26. Kashchak, T.V., \& Hudyma, A.A. (2018). Intensyvnist protsesiv lipidnoi peroksydatsii ta riven markeriv zapalennia $\mathrm{V}$ piznii period kombinovanoi travmy v eksperymenti [Intensity of lipid peroxidation processes and level of inflammatory markers in the late period of combined trauma in the experiment]. Shpytalna khirurhiia. Zhurnal imeni L.Ya. Kovalchuka - Hospital Surgery. Journal named after L.Ya. Kovalchuk, 4, 62-78 [in Ukrainian]. 27. Voronkov, A.V., Pozdnyakov, D.I, Ruri, E.I., \& Rybalko, A.E. (2016). Sravneniye antioksidantnoy aktivnosti meksidola pri povrezhdeniyah golovnogo mozga razlichnogo geneza $\mathrm{v}$ eksperimente [Comparison of the antioxidant activity of Mexidol in brain damage of various origins in the experiment]. Sovremennye problemy nauki i obrazovaniya - Modern Problems of of Science and Education, 6. Retrieved from: http://www. science-education.ru/ru/article/view?id=25392 [in Russian].

28. Takhtfooladi, H.A, Takhtfooladi, H.A., (2019). Effect of curcumine on lung injury induced by skeletal muscle ischemia/ reperfusion in rats. Ulus Travma Acil. Derg., 25 (1), 7-11. Retrieved from: https://doi.org/10.5505/tjtes.2018.83616 PMid:30742297

29. Takhtfooladi, M.A., Takhtfooladi, H.A., Sedaghatfar, H., \& Shabani, S. (2015). Effect of low-level laser therapy on lung injury induced by hindlimb ischemia / reperfusion in rats. Lasers Med Sei., 30, 1757-1762. Retrieved from: https://doi.org/10.1007/ s10103-015-1786-6 PMid:26155904

30. Calapai, G., Squadrito, F., \& Rizzo, A. (1995). Multiple actions of the coumarine derivative cloricromene and its protective effects on ischemic brain injury. Naunyn Schmiedebergs Arch. Pharmacol., 351 (2), 209-215. Retrieved from: https://doi. org/10.1007/BF00169335 PMid:7770103

31. Calapai, G., Marciano, M.C., \& Corica, F. (2000). Erythropoietin protects against brain ischemic injury by inhibition of nitric oxide formation. Eur. J. Pharmacol., 401 (3), 349-356. Retrieved from: https://doi.org/10.1016/S0014-2999(00)00466-0 32. Bilgiç, M.İ., Altun, G., Çakıcı, H., Gideroğlu, K., \& Saka, G. (2018). The protective effect of Montelukast against skeletal muscle ischemia / reperfusion injury: An experimental rat model. Turkish Journal of Trauma and Emergency Surgery, 24 (3), 185190. Retrieved from: https://doi.org/10.5505/tjtes.2017.22208 PMid:29786827
33. Demir, M., Amanvermez, R., \& Kamalı Polat, A. (2014). The effect of silymarin on mesenteric ischemia-reperfusion injury. Med. Princ. Pract., 23 (2), 140-144. https://doi. org/10.1159/000356860 PMid:24356575 PMCid:PMC5586953 34. Aslan, T., Turer, M.D., Joseph, A., \& Hill, M.D. (2010). Pathogenesis of myocardial ischemia-reperfusion injury and rationale for therapy. The American J. of Card, 106 (3), 360-368. Retrieved from: https://doi.org/10.1016/j.amjcard.2010.03.032 PMid:20643246 PMCid:PMC2957093

35. Tarasiuk, V.S., Matviichuk, M.V., \& Palamar, I.V. (2017). Pohliady na tymchasovi metody zupynky krovotechi v umovakh boiovykh dii [Views on temporary methods of stopping bleeding in combat]. Visn. vinnytskoho nats. Med. univers. - Bulletin of Vinnytsia National Medical University, 1 (21), 220-227 [in Ukrainian].

36. Byrne, R.M., Taha, A.G., Avgerinos, E., Marone, L.K., Makaroun, M.S., \& Chaer, R.A. (2014). Contemporary outcomes of endovascular interventions for acute limb ischemia. J. Vasc. Surg., 59 (4), 988-995. Retrieved from: https://doi.org/10.1016/j. jvs.2013.10.054

PMid:24360240

37. Fukuda, I., Chiyoya, M., Taniguchi, S., \& Fukuda, W. (2015). Acute limb ischemia: contemporary approach. Gen. Thorac. Cardiovasc. Surg., 63 (10), 540-548. Retrieved from: https://doi. org/10.1007/s11748-015-0574-3 PMid:26232356

38. Tsymbaliuk, H.Iu. (2018). Stan dobovoho diurezu nyrok v umovakh ishemichno-reperfuziinoho syndromu kintsivok, travmy orhaniv cherevnoi porozhnyny, uskladnenoi hipovolemichnym shokom, ta yikh poiednannia u rannomu periodi travmatychnoi khvoroby [Condition of diurnal diuresis of the kidneys in conditions of ischemic-reperfusion limb syndrome, trauma of the abdominal organs complicated by hypovolemic shock, and their combination in the early period of traumatic disease]. Zdobutky klinichnoi i eksperymentalnoi medytsyny - Achievements of Clinical and Experimental Medicine, 3, 163-169 [in Ukrainian]. 39. Salvadori, M., Rosso, G., \& Bertoni, E. (2015). Update on ischemia-reperfusion injury in kidney transplantation: Pathogenesis and treatment. World J. Transplant., 5, 52-67. Retrieved from: https://doi.org/10.5500/wjt.v5.i2.52 PMid:26131407 PMCid:PMC4478600

\section{ACTIVITY OF CATALASE AND SUPEROXIDE DISMUTASE ON THE BASIS OF EXPERIMENTAL ISCHEMICAL REPERFUSION INJURY OF LIMB}

The aim of the work: to determine the dynamics of superoxide dismutase and renal catalase activity against the background of modifications of ischemic reperfusion injury (IRI).

Materials and Methods. In the experiment 210 non-linear white male rats aged 5-5.5 months were used. The dynamics of the activity of antioxidant enzymes (catalase (Kat), superoxide dismutase (SOD) in the kidney tissue in conditions of modifications of IRI modifications were investigated). The tissue samples were taken 24 hours, 3, 7, 14 days - animals were sacrificed from experiment on the basis of thiopental-sodium anesthesia $(40 \mathrm{mg} / \mathrm{kg}$ of body weight intraperitoneally by total bleeding from the heart. 
Results and Discussion. In our IRI models, Kat level was basically reduced in each experiment period. SOD activity peak was observed in 1, 3 days, and its suppression (for the most groups in 3-rd day) after the experimental IRI - according to the modifications of the severity of the injury. Thus, the use of a haemostatic tourniquet in combination with loss of blood and mechanical trauma caused most significant damage to the antioxidant system of the kidneys. In this case, even a one-time use of the tourniquet caused similar wave-like reactions. In general, the development of IRI is accompanied by a strong inhibition of the antioxidant system of the kidney.

Key words: ischemic-reperfusion syndrome; kidney; trauma; blood loss; haemostatic tourniquet; catalase; superoxide dismutase.

Н. В. ВОЛОТОВСКАЯ, О. И. ЗАРИЧНАЯ, И. П. КУЗЬМАК

ГВУЗ “Тернопольский государственный медицинский университет имени И. Я. Горбачевского МОз Украины”

\section{АКТИВНОСТЬ КАТАЛАЗЫ И СУПЕРОКСИДДИСМУТАЗЫ НА ФОНЕ ЭКСПЕРИМЕНТАЛЬНОЙ ИШЕМИИ-РЕПЕРФУЗИИ КОНЕЧНОСТИ}

Цель работы: установить динамику активности супероксиддисмутазы и каталазы почек на фоне модификаций ишемического реперфузионного синдрома (ИРС).

Материалы и методы. В эксперименте использовали 210 нелинейных белых крыс-самцов в возрасте 5-5,5 месяцев. Исследована динамика активности антиоксидных ферментов (каталаза (Кат), супероксиддисмутаза (СОД)) в ткани почки в условиях моделирования модификаций ИРС. Забор образцов ткани осуществляли через 24 часа, на 3, 7, 14 сутки после травмы. Крысы выведены из эксперимента методом тотального кровопускания с верхушки сердца.

Результаты исследований и их обсуждение. В наших моделях ИРС уровень Кат в основном уменьшался в каждом периоде эксперимента. Пик активности СОД наблюдался на 1, 3 сутки или угнетение (в основном на 3 сутки) после экспериментального ИРС - соответственно с модификациями степени тяжести травмы. Таким образом, применение кровоостанавливающего жгута в сочетании с потерей крови и механической травмой вызвали существенные поражения антиоксидной системы почек. При этом даже однократное применение жгута вызвало подобные волнообразные реакции. Таким образом, развитие ИРС сопровождается выраженным угнетением антиоксидной системы почки.

Ключевые слова: ишемический реперфузионный синдром почки; травма; кровопотеря; гемостатический жгут; каталаза; супероксиддисмутаза. 